\title{
THE POETICS OF THE RIVER IN INDIAN LITERATURE IN ENGLISH
}

\author{
CARMEN ESCOBEDO DE TAPIA ${ }^{1}$ \\ Ángela MENA GONZÁLEZ ${ }^{2}$ \\ University of Oviedo \\ ${ }^{1}$ escobedo@uniovi.es \\ 2U0182604@uniovi.es
}

\begin{abstract}
Water is a natural element that has been universally and religiously recognized as a purifying natural symbol. In India this element acquires special significance from a literary perspective, from poetry to narrative. In a current world that appears to be devoid of spiritual values, where technological modernity is an integral part of our daily experience, it seems necessary to rediscover and recover old sacred values that acquire significant meaning as explained under the eye of an eco-spiritual approach to several examples taken from the corpus of Indian writing in English. In the midst of a world that has turned into a globalised village with hardly any cultural differences, proud as we are of our age of information and communication, it seems necessary to bring forward forgotten values essential to human beings. In Indian writing they can be identified by the symbol of water and the image of the river.
\end{abstract}

Keywords: Eco-poetics, Indian aesthetics, global, glocal, postcolonial, Indian literature in English. 


\title{
LA POÉTICA DEL RÍO EN LA LITERATURA INDIA EN INGLÉS
}

\begin{abstract}
RESUMEN. El agua es un elemento natural que ha sido universalmente reconocido como símbolo religioso de purificación. En India este elemento adquiere especial relevancia literaria, desde la poesía a la narrativa. En el mundo contemporáneo en el que parecen haber desaparecido los valores humanos espirituales y donde los avances tecnológicos consituyen parte integral de nuestra experiencia cotidiana, es necesario redescubrir y recuperar antiguos valores sagrados que adquieren una nueva dimensión a través de una aproximación eco-espiritual a un determinado corpus de textos en el ámbito de la literatura india en lengua inglesa. En un mundo, que se ha convertido en un 'pueblo global' donde las diferencias culturales parecen haberse matizado y orgullosos como estamos de la Era de la Información y la Comunicación, se deberían recuperar valores humanos esenciales que han sido olvidados. En el ámbito de la literatura india, podemosidentificarlos mediante un análisis del símbolo del agua y a través de la imagen del río, tal y como se representa en algunos ejemplos que analizamos en este artículo.
\end{abstract}

Palabras clave: Eco-poética, estética india, global, glocal, postcolonial, literatura india en inglés.

Received 11 March 2016

Revised version accepted 12 December 2016

In this paper we discuss the need to change and foresee new directions and trends in a postcolonial critical approach to the literary text. In the Era of Globalization, where humankind seems to be, or should be, closer than ever due to technological and communication advances, where the global society should work for a recognition of local identities imbribed in the concept of glocalization, terms like multiculturalism should imply tolerance and respect among nations and societies. It seems that the universal spiritual values that drive humans together and should make the true understanding and communication among people possible have been lost in the void of immediacy. New generations do not understand the pleasure of calm talk, of inner reflection, of spiritual concentration that would lead in turn to personal discovery and, therefore, to a better attitude towards tolerance and respect. In our lives, led by the electronic media and the information technology, we find little time for personal quests.

We could argue then that postcolonial criticism should shift its main interest from an anthropocentric view, that is, a human-centred approach where social justice is the most important battle, to a more life-centred (bio or ecocentric) one. We may talk of an ethical turn: "there has been a shift in modern critical sensibility closely allied to the ethical turn, which is a conscious bringing to the surface of 
postmodernism's/poststructuralism's underlying social and moral concerns" (Goodbody and Rigby 2011: 242). Its traditional concerns, namely "an analysis of the relationship between self and other, an attempt to find new models of community; an interrogation of human subjectivity and, in some extreme cases, a challenging of the category of the human itself" (242), seem to converge within two fields of critical inquiry despite their apparently contrasting interests.

The definitions of postcolonialism provided by several critics claim the interdisciplinarity of postcolonial studies (Eagleton 1999: 24-26). By looking at the work of prominent ecocritics, it seems that they also aim for an interdisciplinary approach (Quayson 2000). Glen Love analyses the relationship between literature and the physical environment and talks of "the multiplicity of subjects and approaches" (2003: 25). He also suggests that "an extension of morality to the non-human world implicitly challenges literary studies" (25) and provides wider angles to our "limited human vision, (and its) narrowly humanistic perception of what is consequential in life" (25).

Therefore, we can asume that the postcolonial critic in the twenty-first century should become ecologically minded in order to read the value of nature as shown in the literary text. This would help and affect the consciousness of people so as to realize the importance of considering natural elements and their image in the literary text as tools to rediscover the importance of Nature in our relationship with the world, with others and with the environment itself.

Water is a natural element that has been universally and religiously recognized as a purifying symbol. Watercourses conform to the "universal law of circulation that governs all forms of vitality" (Schama 1995: 50). Water is a central element of the human body, seventy per cent of its mass is water and thus it constitutes our main life force:

Every organ in the human organism is originally born of water: the forms of the joints, of the limbs with their convoluted bones, of heart and blood vessels, of ears, brain and sense -organs- the forms, in short, of all the functional systems... we can see in water a reflection, so to speak, of the human being. (Spock 1989: 125)

So the importance of water is not only metaphorical or symbolical, it is something that has to be considered inherently linked to our physical daily flow. Our brain stores memory and texts posit other kinds of memory which link the individual and collective experiences. We, as living entities, hold memory in liquid form. Water interconnects the experiences of (hu)mankind and blood memory is the genesis for creative expression. Thus, water stands as a universal primary natural element that holds no borders, and trascends and becomes a seat of 
cultural memory genesis for creative expression (Wardi 2011). As Toni Morrison's reading of the Mississippi River recalls:

You know, they straightened out the Mississippi River in places, to make room for houses and livable acreage. Occasionally the river floods these places. "Floods" is the word they use, but in fact it is not flooding; it is remembering. Remembering where it used to be. All water has a perfect memory and is forever trying to get back to where it was. Writers are like that: remembering where we were, what valley we ran through, what banks were like, the light that was there and the route back to our original place. It is emotional memorywhat the nerves and the skin remember as well as how it appeared. And a rush of imagination is our "flooding". (In Spock 1989: 125)

In India, this element acquires special significance from a literary perspective, from poetry to narrative, and thus we can analyse different examples in order to make explicit the intrinsic spintual and religious content underlining the use of the image of the river by Indian writers:

One could say that each of us -every man, woman and child- is a small river; ebbing... flowing... seeking replenishment. A 1-percent deficiency of water in our body makes us thirsty; 5-percent causes a slight fever; at 10-percent we become immobile. A 12 percent loss of water and we die. There is no option, no alternative, no substitute. From the elderly to the young, the rivers within each of us need continuous supply of clean, fresh water. (Swanson 2001: 150)

In our current world, which appears to be devoid of spiritual values and where technological modernity is an integral part of our daily experience, it seems necessary to rediscover and recover old sacred values that acquire significant meaning as explained under the eye of an eco-spiritual approach (Held 2006; Heise 2008; Huggan and Tiffin 2010; Sivaramakrishnan 2012), thus attempting to clean and purify, as in a cyclic renewal, the polluted streams that flow nowadays. In a world that has turned into a globalised village with hardly any cultural differences, proud as we are of our age of information and communication, it seems necessary to bring forward forgotten values essential to human beings. In Indian writing they can be identified by the symbol of water and the image of the river.

We seem to live in a world of make believe, our lives splashed by the electronic media and led by information technology. As pointed out before, there seems to be little space for personal quests and less even for an observation of the environment, or any spiritual conception of the world. Human beings have always searched for truth in one way or the other, and behind that search for truth lie the grand questions of life and death, pain and pleasure, body and soul, the 
suffering self in the middle of an all pervasive nature. It seems that the West, has forgotten about all this and turning our eyes towards other more spiritual cultures might help us re-discover our past in order to re-read the present, so as to foresee a future of mutual understanding and true communication among cultures and human beings. This paper aims to illustrate how an eco-spiritual approach to the literary text will help us identify the sacred and spiritual implications through the image of water, more specifically the rivers, as used by Indian authors.

Rivers in India, the same as in other cultures, have always been associated with the sacred. It might seem necessary to recall the time after the European Enlightenment, when the Western patterns of progress and human development were based on a hegemonical discourse of science and technological advance. These came to be considered the universal, ondered and rationalized vision for the whole mankind. In this context, texts emerged like Siddhartha, by Herman Hesse, in which the author fought to give significance to profound human longings. This was a common attitude at the time: Western scholars turned their eyes to the East in search of its spirit, not in an attempt to dominate but to give answer to the essence of our being through silence, understanding and reverence of the sacred.

The time has come again when academics and non-academics look towards cultures like India to help us discover Eastern religious and spiritual values and therefore learn and apply new ways of living and thinking to the Western and even universal current patterns of thought. Siddhartha can, then, be our reference. There is a specific part at the end of the book where he sits besides the river in an attempt to communicate with it:

Siddhartha listened. He was now listening intently, completely absorbed, quite empty, taking in everything. He felt that he had now completely learned the art of listening. He had often Heard all these before, all these numerous voices in the river, but today they sounded different... And all the voices, all the goals, all the yearnings, all the sorrows, all the pleasures, all the good and evil, all of them together was the world. All of them together was the stream of events, the music of life. (Callicot and Ames 1991: 107)

Therefore, we may adopt this same attitude and place ourselves as unique individuals, as sensitive souls, agglutinating the questing minds of the West and the compassionate soul of the East. We should attempt to interpret and explain the contemporary world from an ecologically sensitive theorizing and interpretation of texts. Hence, in our re-reading of the chosen texts, we should depart from our conceptualization of the truth and meaning of life as part of non-human nature, particularly approaching the image of the river. We should consider the symbol of 
water in its purifying significance, ultimately wishing to call for a reordering of our present value system. The same as Siddhartha, in his search for the meaning of his life, we will try to unveil the spiritual value that the image of the river underlies and that can be applied to our present, moving among us as more real than any virtual images of our selves lost in the contemporary Western consumer culture.

To illustrate the previous theorerical considerations and reflections, we will provide an eco-spiritual re-reading of The Serpent and The Rope (1960) by Raja Rao, The Inheritance of Loss (2006) by Kiran Desai, and the poem "Simple Contradictions" (2010) by S. Murali Sivaramakrishnan, as representative voices from the postcolonial to the contemporary and global in Indian Literature in English. This critical approach reintegrates the conceptual and experiential aspects of nature into critical theory, parallel to other aspects like gender, class and race. As S. Murali states:

As the critical inquiry informed by the mores of cultural studies progressed it naturally became necessary to incorporate the presence and significance of nonhuman nature at the core of human understanding and to reinstate it at the central position from the peripheral where it had been discarded earlier. (2012: 5)

The Serpent and The Rope ${ }^{1}$ is a journey of discovery, apparently of intellectual discovery, but from an eco-spiritual reading we can conclude that Rama is in search of Spiritual Truth, his spitirual truth, his true inner self. In this search, his relationship with rivers and the image of water is very significant. The whole novel is full of rivers that become natural witnesses of Rama's inner search. It all leads to the Ganga River, the only river next to which he finds peace and feels communion with the environment. Mother Ganga stands for the sacredness of all the rivers of India:

The Ganga is the river of India -a single river flowing from the Himalayas, gathering tributaries, and streaming across the fertile plains of north India. At the same time, the Ganga is the source of all sacred waters everywhere in India. The Gangā is also a goddess -GangāMātā, "Mother Gangā," and GangāDevī, "Goddess Gangā." Her true headwaters are not really in the highest Himalayas, but are said to be in the highest heaven, emerging from the very foot of Vishnu. She was carried in the water pot of Lord Brahmā, and when she plummeted from heaven to earth, her cascades fell first on the head of Lord Shiva. (Eck 2012: 2590-5)

\footnotetext{
1 From now on TSR.
} 
Rama does not sit next to the river attempting to listen to it as Siddhartha did, but moves between India and Europe in search of his true self, facing the image of the European rivers and trying to detect in them his true Indian soul, which always flows among the waters of Mother Ganga. He finds himself lost in an intercultural journey, where he eagerly looks for Indian traits. That is why he always refers to the Ganga River as if it was a mantra. His spirit rests upon the memory of the Ganga River wherever he goes, and tries to identify its reverberations and shadows in all the rivers he comes across throughout his journey: the Thames, the Seine, the Rhone, the Cam... Rivers flow throughout the narrative as if it was Rama's spirit and bridges cross over rivers trying to bring cultures together.

From an eco-spiritual approach, we could conclude that Rama moves in a postcolonial context in which individuals search for identity. He wants to bridge the gap between the East and the West. Rama aims to find the limits between the real and the illusory to achieve the Advaitic wisdom, and here lies the importance of considering the image of water: "Waves are nothing but water. So is the sea" (Rao 1960: 68).

This is crucial, as it links with the sacred value of existence. We should live life as an inexhaustible experience, and thus search for the spiritual at the heart of being. We are waves, our individual inner experiences are primarily linked to our inner sense, but from here we should be socially awakened. Our commitment with the wretched of the Earth requires a symbiotic relationship between selfawareness and the collectivity of society. We are waves that pour into the waters of existence, the sea. Here lies, in turn, the ancient Indian idea of state that incorporated both perspectives: the vyashti (the individual) and samashti (the collective). Underlying this we identify the need to join love and reason together.

In the contemporary world we seem to have lost this ability, moved by the force of reasoning. Hence, this should be the ultimate expression of an ecospiritual reading of TSR: to join together the ability to love and reason, to project efficiently the action of intellect, intuition and the senses. Rama failed to love, and thus he lost his balance. He needed purification of his self and wanted to find the reason for his existence; the river, Mother Ganga, guided his quest. In the end, he went back to Travancore, where he finally found peace. He achieved a selfrealization of eco-dharma. This is what we should aim for in the contemporary world: to exist as independent beings, as waves, and also be able to love all and everything simultaneously, as socially and spiritually responsible beings in the ocean of a Global Era. 
The Inheritance of Loss ${ }^{2}$ is a novel with an intense ecological force. Landscape and rivers together drive the reader through a spiritual reflection and restoration. It is set in what the British called the Indian hill station, which stood for the image of virgin landscapes and the Garden of Eden: Darjeeling, a region in West Bengal that was first discovered as a retreat settlement by the East Indian Company in 1827, where the Eden Sanitarium was built. Kalimpong is the area at the foot of the Hymalayan range where the protagonist, Sai's grandfather, a broken and reclusive retired judge, bought Cho Oyu (name that comes from the sixth highest peak in the world) in 1957 (Kennedy 1996).

The novel starts describing the view from the veranda, and we are told by an omniscient narrator that the old man chose the place attracted by the peace and solitude he was searching for. He was driven there, it seems, by a profound desire to retreat from society as he struggled to bring back peace to his tormented soul, overwhelmed by a sense of self hatred and an acquired distaste of all Indian things. The narration depicts a search for identity through the spiritual settlement of the protagonist. We, as readers, realize the need to find comfort in our inner selves, to be in peace with our past in order to maintan the balance of our existence.

We learn that thirty years earlier he had discovered the place as "passionately colored birds swooped and whistled, and the Himalayas rose layer upon layer until those gleaming peaks proved a man to be so small that it made sense to give it all up, empty it all out" (Desai 2006: 29), whence we can infer that the judge felt the sacred call of the Himalayas, which would help him escape from his troubled past. So, from the very first page, we are led into considering that Cho Oyu should stand for the icon of retreat and spiritual restoration.

The Hymalayan mountains are said to rise up to Heaven, next to the gods, and therefore the whole setting seems to be ideal for inner reflection, surrounded by both the picturesque and the sublime (De Loughrey and Handley 2011). The environment, in this particular case, does not acquire negative implications but drives the soul to heaven and peace. In this magnificent sacred natural setting, Desai includes also the image of the river; we first encounter it when Sai, the judge's granddaughter, first amives in Cho Oyu, and her first impression of the place links with her grandfather's inner desires:

Suddenly to the right, the Teesta River came leaping at them between white banks of sand. Space and sun crashed through the window. Reflections magnified and echoed the light, the river, each adding angles and colors to the

\footnotetext{
2 From now on TIL
} 
other, and Sai became aware of the enormous space she was entering. By the riverbank, wild water racing by, the late evening sun in polka dots through the trees, they parted company. To the east was Kalimpong, barely managing to stay on the saddle between the Deolo and the Ringkingpong hills. To the west was Darjeeling, skidding down the Singalila Mountains. (Desai 2006: 31)

This beautiful description of the flow of the Teesta River fills the environment with light, reflections and colours, and what seems a mere geographical standpoint acquires a new dimension through an eco-spiritual approach. Even more if we take into account that this image of the past no longer exists; just twenty years ago, the river flowed fast and strong, sustaining the lives of millions of people. But the Teesta has now been reduced to a trickle in northern Bangladesh, and many affected villagers have been staging protests in the capital Dhaka and elsewhere. Nothing is left of the mighty Teesta as it was two decades ago. There has been no fish in the river for the last few years and it is almost dried up ${ }^{3}$.

Everything points to the magnificence, the grandeur, the beauty and freshness of the landscape in the past, which gives shelter to Sai's young spirit, which breaks into the judge's life to soften and comfort his soul. Water here is linked to the playful, joyful heart of the girl, which would in turn purify the soul of the judge, and lead him in his redeeming quest. At the same time, we realize how in the name of progress many wild corners have been damaged to the verge of destruction. We certainly recall corners of our childhood that used to be and are no more, and this recalling of past landscapes comforts and restores our spirits, and should renew our perspective of the current world. Our emotional memory is moved by the narrative flow: "It is remembering. Remembering where it used to be. All water has a perfect memory and is forever trying to get back to where it was" (Wardi 2011: 79).

The next reference to a river that appears in the flow of the narrative is linked to the feelings of another character, Biju. He is an illegal Indian immigrant, alone in the city of New York, trying to get a green card that never comes, jumping from job to job, treated almost like a slave in what he thought the land of opportunities and progress:

It had turned to winter. The shadows drew in close, the night chomped more than its share of hours. Biju smelled the first of the snow and found it had the same pricking, difficult smell that existed inside the freezer; he felt the Thermocol scrunch of it underfoot. On the Hudson, the ice cracked loudly into

For further information: Roy, P. http://www.thethirdpole.net/teesta-river-runs-dry-as-india-andbangladesh-fail-to-resolve-disputes/ 
pieces, and within the contours of this gray, broken river it seemed as if the city's inhabitants were being provided with a glimpse of something far and forlorn that they might use to consider their own loneliness. (Desai 2006: 51)

The Hudson River, shadows, night, winter, ice... gloomy images of the Western cartography match the inner feelings and spiritual unsettlement of Biju's shocked sadness, who feels profound loneliness and depression in the unwelcoming cosmopolitan metropolis par excellence. Suddenly, the iced river cracks and leaves out the natural purifying element which, though cold, seems to drive Biju back to a warm past, his childhood in India. It is a reminder to the inhabitants of the city of the need to go back to the sacred natural liquid to purify our own feelings of loneliness in this automated individualistic world.

Our spirits here are stirred, but in a different way. It is like a warning to the West. We find here, thus, the representation of an aggressive damaging West that contrasts with the memories of a happy childhood in India, which are also linked to the image of the Yamuna River and the rural life surrounding it. Like the Ganga the Yamuna is seen as a river of Heaven, indeed the daughter of the Sun. Like the Gangā, she carries the waters of purification. But the Yamunā carries something else that is quite distinctive: the waters of love (Eck 2012):

Lying on his basement shelf that night, he thought of his village where he had lived with his grandmother on the money his father sent each month. Down a dry gully through the grasses, you reached a tributary of the Jamuna where you could watch men travelling downstream on inflated buffalo skins [...] Here, at this shallow place, Biju and his grandmother would cross on market trips into town and back, his grandmother with her sari tucked up, sometimes a sack of rice on her head. Fishing eagles hovered above the water, changed their horizontal glide within a single moment, plunged, rose sometimes with a thrashing muscle of silver. A hermit also lived in this bank, positioned like a stork, waiting, oh waiting, for the glint of another, an elusive mystical fish; when it surfaced he must pounce lest it be lost again and never return. . . On Diwali the holy man lit lamps and put them in the branches of the peepul tree and sent them down the river on rafts with marigolds -how beautiful the sight of those lights boobing in that young dark. (Desai 2006: 102-3)

Biju's childhood memories drive him back to the figure of a loving grandmother; thus, the Yamuna River symbolically stands for a comforting flow of memories that recall love and spiritual pureness, identified in the figures of a grandmother and a hermit. India, then, is linked to a more loving and spiritual representation, as opposed to an image of the West that oppresses and destroys the spiritual balance of the character: 
He remembered bathing in the river, feeling his body against the cool firm river muscle, and sitting on a rock with his feet in the water, gnawing on sugarcane, working out the sweetness no matter how his jaw hurt, completely absorbed. (Desai 2006: 270)

His memories give him strength when in contact with the waters of the Yamuna River. Biju seems to try to bring back his past to purify his present, his tormented soul betrayed by social injustice, and in this exercise might want us, westerners, to realize the need for a revision of ourselves in order to achieve more tolerance and solidarity in what has come to be a global multicultural world.

Our last example is "Simple Contradictions" (Sivaramakrishnan 2010: 23-24). This poem drives the reader back and forth in an exercise of nostalgic remembrance. Sankara, the philosopher, the guru, left home at the age of eleven seeking sanyasa. Afer years of wandering, he sits now beside the great river, the mighty Narmada River. It is one of India's most beautiful, fascinating and controversial rivers nowadays. A dam has been built and thousands of people have been thrown out of their homes.

Because it is considered sacred all along its banks, the Narmadā is the one river in India with a prescribed pilgrimage of parikrama or pradakshina, circumambulation. No other river, not even the Gangā, has such a detailed accounting of all the holy places along its banks. There are one hundred and twenty-three tirthas before reaching Amarakantaka (the sea), and four hundred and eighty-one on the whole circuit. Like the Gangā, the Narmada is said to be divine in origin. The local māhätmyas describe Narmadā savatarana as she tumbles from the head of Lord Shiva to earth. The Narmadā, like the Gangā, is intimately associated with Shiva and is often said to flow from his divine body. The Narmadā is referred to as the daughter of Shiva, just as Gangā is known as his co-wife. Narmadā is said to be a brahmachārinī, a celibate and pure woman (Eck 2012: 3406-3444).

Just like Siddhartha, Sankara, the philosopher, sits trying to listen and trying to recover the essence of his soul. He hears his mother's clear voice across its waters, calling Sankara, Sankara, Sankara, as if it were a mantra. He renounced life, but now, in front of the sacred waters of the Narmada, in front of the view of a completely distorted image of his past, "of memory and anguish... here beside the river once again I stand alone", and he realizes that what once used to be is not anymore. Through the remembrance of past memories that have been erased in the name of progress, he walks about "in the darkness of human ignorance, in the tiny circle of light. Seeking myself forever", which are the last lines in the poem. 
Once more, the sacred view and sound of the river is the excuse for the spiritual quest and understanding. The sight of a river that has been dramatically affected by the capricious hands of human progress makes the old philosopher search for his spiritual settlement. Going back to the past and getting immersed in meditation, he feels lost and in loneliness, surrounded by the sacred waters of the river that make us flow, and drives this analysis back to where we started, as a circle of light to understanding.

As a conclusion, we can say that the use of the image of rivers made by Indian authors and their interpretation through an eco-spinitual re-reading causes a purifying effect on us, Western readers. This approach aims to cause a process of reflection that eventually and ideally should produce a new fresh image of ourselves and our view of the world. The poetics of the river in the Indian literary context is definitely linked to the sacred and religious values of the Indian tradition. In turn, we find that those become, at the same time, bridges between the East and the West, present and past.

The eco-spiritual re-reading of these works helps Western readers realize the importance of turning our attention to cultures like India, and reaffirms the need to re-read the postcolonial texts in the light of new approaches that would help us recover lost universal values of existence. Therefore, as it has been proved through this analysis, postcolonial literatures, globalized literatures, such as Indian Literature in English, can now be recognized as intercultural bridges that would eventually contribute to unite the universal soul of human beings in the contemporary global world we live in.

\section{REFERENCES}

Buell, L. 2005. The Future of Environmental Criticism: Environmental Crisis and Literary Imagination. Malden, MA: Blackwell.

Callicott, J. B. and R. T. Ames, eds. 1991 (1989). "A Metaphysical Grounding for Natural Reverence: East-West". Nature in Asian Traditions of Thought: Essays in Environmental Philosophy. Delhi: Sri Satguru Publications.

DeLoughrey, E. and G. B. Handley, eds. 2011. "Cultivating Community: Counterlandscaping in Kiran's Desai's The Inheritance of Loss". Postcolonial Ecologies: Literatures of the Environment. Oxford: Oxford University Press.

Desai, K. 2006. The Inheritance of Loss. New Delhi: Penguin Books.

Eagleton, T. 1999. 'Postcolonialism and 'Postcolonialism'. Interventions 1 (1).

Eck D. L 2012. India: A Sacred Geography. Harmony Books: Kindle Edition. 
Goodbody, A. and K. Rigby. 2011. Ecocritical Theory: New European Approaches. Virginia: University of Virginia Press.

Heise, U. K. 2008. Sense of Place and Sense of Planet: The Environmental Imagination of the Global. Oxford: Oxford University Press.

Held, V. 2006. The Ethics of Care: Personal, Political, Global. Oxford: Oxford University Press.

Huggan, G. and H. Tiffin. 2010. Postcolonial Ecocriticism: Literature, Animals, Environment. London: Routledge.

Kennedy, D. 1996. The Magic Mountains: Hill Stations and the British Raj. Berkeley: University of California Press.

Love, G. A. 2003. Practical Ecocriticism: Literature, Biology and the Environment. Virginia: University of Virginia Press.

Murphy, P. D. 2009. Ecocritical explorations in Literary and Cutural Studies. Lanham, MD: Lexington Books.

Oppermann, S., Ufuk, O., Ozkan, N. and S. Slovic. 2011. The Future of Ecocriticism. Newcastle upon Tyne: Cambridge Scholars Publishing.

Quayson, A. 2000. Postcolonialism: Theory, Practice or Process? Cambridge: Polity Press.

Rao, R. 1960. The Serpent and the Rope. New Delhi: Penguin Books.

Roy, P. "Teesta river runs dry as India and Bangladesh fail to resolve disputes". $<$ http:// www.thethirdpole.net/teesta-river-runs-dry-as-india-and-bangladeshfail-to-resolve-disputes/ >. (Accessed January 2015)

Schama, S. 1995. Landscape and Memory. New York: Knoff.

Sivaramakrishnan, M. 2010. The East-Facing Shop and Other Poems. Kolkata: Monkafira Books.

Sivaramakrishnam, M. and C. Lourdes, eds. 2012. "Echoing Eco-Spiritual Values for a New World". Inter-Readings: Text, Context, Significance. Chennai: Versa Books.

Spock, M. 1989. Water: The Element of Life. Hudson, New York: Anthropomorphic Press. 125.

Swanson, P. 2001. Water: The Drop of Life. Minnesota: NorthWord Press.

Wardi, A. J. 2011. Water and African American memory: An Ecocritical Perspective. Gainesville: University Press of Florida.

Zinsser, W., ed. 1987. Inventing the Truth: The Art and Craft of Memoir. Boston: Houghton Mifflin. 


\section{APPENDIX}

\section{"Simple Contradictions"}

(by Murali Sivaramakrishnam)

I am Sankara, the yogi who left home

When barely eleven. I am philosopher

Scholar. Guru and friend to many, now seated

Beside the mighty Narmada. My time

Moves backwards and forwards-

I am child, Sivaguru's son,

Seeking sannyasa, and my mother's blessing

Willed and destined through the act of the crocodile

To wander forthwith across the western-ghats

Traverse jungles and deserts, across many rivers.

I have come face to face with scholars and pundits,

Poets and philosophers, beggars and kings.

When did I ever shy away from action?

Now seated beside the great river

Having conversed with many a sensitive soul

I Hear my mother's clear voice from across the waters.

Calling, Sankara, Sankara, Sankara...

Since when has a sannyasin ever returned home?

What is home for one who has renounced all?

What meaning does relationship hold forth

For the one who seeks the brahman's awesome embrace?

Time does nothing, neither do we

Who with folded hands move round in circles and silence

Surrounded with dreams and desires.

My mother's cry resounds once more.

I must return and carry out her final rites- -

Her passage and mine across the mighty waters

Of memory and anguish.

Barking of the village dogs greet me in my native land

Fear and panic spread like huge green banana leaves

As the sannyasin descends the steps to do the ancient rites.

Here beside the river once again I stand alone-

I who have learned and taught so much and yet so little.

I am Sankara, the yogi who left home

When barely eleven. I am philosopher

Scholar, guru, friend to many, now seated

Beside the burning pyre. Learning and unlearning

Walking about in the darkness of human ignorance

In the tiny circle of light. Seeking myself forever. 